\title{
Leaf litter as a possible food source for chironomids (Diptera) in Brazilian and Portuguese headwater streams
}

\author{
Marcos Callisto ${ }^{1}$; José F. Gonçalves Jr ${ }^{1} \&$ Manuel A. S. Graça ${ }^{2}$
}

\author{
${ }^{1}$ Laboratório de Ecologia de Bentos, Departamento de Biologia Geral, Universidade Federal de Minas Gerais. Caixa Postal \\ 486, 30161-970 Belo Horizonte, Minas Gerais, Brasil. \\ ${ }^{2}$ Departamento de Zoologia, Universidade de Coimbra. 3004-517 Coimbra, Portugal.
}

\begin{abstract}
Our objective was to evaluate the potential use of leaf detritus by chironomid larvae. Field and laboratory experiments were performed using leaves and chironomid species collected in Portugal and Brazil. Laboratory experiments under controlled conditions were done using microbial conditioned senescent leaves of Alnus glutinosa (L.) Gaertn, Nerium oleander L., Protium heptaphilum (Aubl.) March, Protium brasiliense (Spreng) Engl., Myrcia guyanensis (Aubl.) DC and Miconia chartacea Triana. Laboratory experiments were performed using specimens collected from leaf litter in local streams. Whenever possible, after the experiments, chironomids were allowed to emerge as adults and identified. In Portugal the following taxa were identified: Micropsectra apposita (Walker, 1856), Polypedilum albicorne (Meigen, 1838), Eukiefferiella claripennis Lundbeck (1898), Rheocricotopus (Psilocricotopus) atripes Rempel (1937) and Ablabesmyia Johannsen (1905) (Diptera, Chironomidae). Consumption rates ranged from $0.15 \pm 0.10 \mathrm{mg}$ (AFDM) of leaf animal ${ }^{-1}$ day $^{-1}$ (Micropsectra apposita feeding on Alnus glutinosa) up to $0.85 \pm 0.33 \mathrm{mg}$ (AFDM) of leaf animal $^{-1}$ day $^{-1}$ (Polypedilum albicorne feeding on Miconia chartacea). In Brazil, the following taxa were identified from leaves: Phaenopsectra sp., Chironomus spp. and Polypedilum sp. and maximum consumption rates reached $0.47 \pm 0.28$ (AFDM) of leaf mg.animal ${ }^{-1}$.day ${ }^{-1}$ (Chironomus Meigen (1803) feeding on Protium heptaphilum). Feeding experiments with laboratory cultured specimens, revealed that some chironomids were unable to feed on decomposing leaves (e.g., C. xanthus Rempel (1939) on P. brasiliensis and M. guyanensis). Our results suggest that some stream chironomids (not typical shredders) can use leaf litter of riparian vegetation as a complementary food source.
\end{abstract}

KEY-WORDS. Leaf feeding; shredders; tropical and temperate experiments.

RESUMO. Detritos foliares como possível fonte de alimento para Chironomidae (Diptera) em riachos de cabeceira brasileiros e portugueses. $\mathrm{O}$ objetivo foi avaliar o potencial uso de detritos foliares por larvas de Chironomidae. Foram realizados experimentos em campo e em laboratório utilizando folhas e larvas de Chironomidae coletadas no Brasil e em Portugal. Foram realizados experimentos em laboratório em condições controladas utilizando detritos foliares (Alnus glutinosa (L.) Gaertn., Nerium oleander L., Protium heptaphilum (Aubl.) March, Protium brasiliense (Spreng) Engl., Myrcia guyanensis (Aubl.) DC e Miconia chartacea Triana) após a colonização microbiana. Experimentos laboratoriais de consumo foram realizados com espécies coletadas em detritos orgânicos em riachos locais. Depois dos experimentos, quando possível, os exemplares foram deixados atingir o estágio adulto e identificados. Em Portugal foram identificadas as seguintes espécies: Micropsectra apposita (Walker, 1856), Polypedilum albicorne (Meigen, 1838), Eukiefferiella claripennis Lundbeck (1898), Rheocricotopus (Psilocricotopus) atripes Rempel (1937) e Ablabesmyia Johannsen (1905). As taxas de consumo variaram entre 0,15 $\pm 0,10 \mathrm{mg}$ de folha animal ${ }^{-1}$ dia $^{-1}$ (Micropsectra apposita alimentando-se de Alnus glutinosa) e 0,85 $\pm 0,33 \mathrm{mg}$ de folha animal ${ }^{-1}$ dia $^{-1}$ (Polypedilum albicorne alimentando-se de Miconia chartacea). No Brasil foram identificados os seguintes taxa: Phaenopsectra sp., Chironomus spp. e Polypedilum sp.; a taxa máxima de consumo foi 0,47 $\pm 0,28$ de folha mg.animal ${ }^{-1}$ dia $^{-1}$ (Chironomus Meigen (1803) alimentando-se de Protium heptaphilum). Foram igualmente feitos testes com estirpes laboratoriais de Chironomidae, algumas das quais não foram capazes de alimentarem-se de folhas em decomposição (e.g. C. xanthus Rempel (1939) em P. brasiliense e M. guyanensis). Os resultados sugerem que alguns Chironomidae (não tipicamente fragmentadores) podem utilizar detritos foliares de vegetação ripária como fonte complementar de alimento.

PALAVRAS-CHAVE. Alimentação de folhas; fragmentadores; experimentos em região tropical e temperada.

Allochthonous organic matter of terrestrial origin is an important component of streams in forested areas and a major energy source consumer (Pozo et al. 1997, АвеLно 2001). Litter input to streams can reach up to $1,500 \mathrm{~g}$ (AFDM). $\mathrm{m}^{-2}$. year ${ }^{-1}$ and standing stock values up to 3,000 g (AFDM). $\mathrm{m}^{-2}$ have been reported, being leaves the largest litter component (AвELHo 2001).

Revista Brasileira de Zoologia 24 (2): 442-448, junho 2007 
Leaf litter is generally present all year around in tempered and tropical streams (RAmirez et al. 1998, GonZALEZ \& GraçA 2003) and processed in situ by microorganisms and invertebrates (Gessner \& Chauvet 1994, Gessner et al. 1999, GraçA et al. 2001). Microbial colonization enhances the palatability of leaves to invertebrate consumers, including trichopterans, plecopterans, amphipods and tipulids (Graça 2001, Graça et al. 2001).

Chironomids are an important component of the invertebrate assemblages in virtually all water bodies, and in many cases numerically dominant (COFFman \& FERrington 1996, RAMIREZ et al. 1998, Rincon \& Cressa 2000, Graça et al. 2004). In some Portuguese streams GraçA et al. (2004) referred that chironomids complied around 1,200 individuals $\mathrm{m}^{-2}$, whereas in pristine Brazilian streams of Serra do Cipó, GaldeAn et al. (2000) reported chironomid densities up to 1,600 individuals $\mathrm{m}^{-2}$. Values up to 2,000 individiduals. $\mathrm{m}^{-2}$ were reported in a Canadian (Ontario) stream (Tavares-Cromar \& Williams 1997). Chironomids are among the taxonomic groups with high production in streams (Meyer \& Poepperl 2003). Chironomids are also very diverse and distributed world wide. The number of estimated species ranges from 1,000 to 2,000 in Europe (IlLies 1978) and c. 10,000 for Brazil (E.J. Fittkau, pers. com.), but less than 10\% are already known.

Chironomid larvae are known to ingest a variety of food types, e.g., algae, detritus and associated microorganisms, macrophytes, woody debris and invertebrates (BERG 1995, HirABAYASHI $\&$ WotTon 1999). Most of the chironomid species are considered gathering-collectors and to a lesser extent predators (Tanypodinae), miners (e.g., Stenochironomus Kieffer, 1919, Endochironomus Kieffer, 1921, Goeldichironomus Fittkau, 1965, and some Orthocladiinae) and shredders (GrubBs et al. 1995, Coffman \& Ferrington 1996). However, several studies have shown that many aquatic invertebrates are opportunistic or generalists (polyphagous), feeding on other sub-optimal food sources (Friberg \& Jacobsen 1994, Minuc \& Minuc 1995, Dangles 2002) and the same may apply to chironomids in general.

Chironomids are sometimes present in large numbers in decomposing leaves (Reice 1980) and in litterbags or leaf packs of decomposing experiments (Grubbs et al. 1995, CASAs et al. 2000, Menendez et al. 2003). In a Brazilian shallow lake (Jurubatiba lagoon, Rio de Janeiro) 21 genera of Chironomidae were observed in decomposing leaves of Typha dominguensis Pers. (Gonçalves et al. 2000) and 9 genera in Nymphaea ampla (Salisb.) DC (GonçaLves et al. 2003). In a decomposition experiment GRUBBs et al. (1995) reported that typically > 75\% of invertebrates colonizing leaves were chironomids, but only 1 to $23 \%$ were shredders; a total of 37 chironomid genera were identified in decomposing leaves. Pope et al. (1999) reported that 24 to $94 \%$ of the invertebrates associated to decomposing leaves in a Canadian Lake were chironomids; however, it was assumed that chironomids were using leaves as habitat. There are also been references for consumption of entire leaves by chironomids (Berg 1995, Canhoto \& Graça 1999).
Since leaves in many small streams are conspicuous and chironomids are numerous, it is plausible that many chironomids may use leaf litter as potential alternative energy source. As stated before in Gonçalves et al. (2006b), the role of aquatic invertebrate consumers in leaf-litter processing is unclear outside temperate systems. In this paper we evaluated the capability of a range of chironomids to feed on conditioned leaves. Specimens were collected in some streams from two climates: temperate (Portugal) and tropical (Brazil) areas in order to cover two different climatic zones.

\section{MATERIAL AND METHODS}

\section{Field experiment}

In a first experiment we assessed the numerical importance of chironomids in decomposing litter in streams. Senescent leaves of Nerium oleander were collected during autumn, air dried and assembled in portions of $4.0 \mathrm{~g}( \pm 0.2 \mathrm{~g})$ and allocated into bags with mesh sizes of $10 \mathrm{~mm}$ (coarse mesh bags), $0.5 \mathrm{~mm}$ and $0.25 \mathrm{~mm}$ (fine mesh bags). Twenty four bags were prepared and placed in a side channel of the S. João stream, Lousã (Central Portugal). The channel was $10 \mathrm{~cm}$ deep, $0.5 \mathrm{~m}$ wide and has natural substratum of pebbles and gravel. The bags were recovered after 45 days (February-March 2003), transported to the lab and the invertebrates retrieved in white trays. Invertebrates were counted and classified into two categories: Chironomids and other invertebrates. The remaining leaf material was dried at 50 ${ }^{\circ} \mathrm{C}$ for at least 48 hours and the percentage of remaining mass calculated after correction for air to oven dry mass.

\section{Laboratory experiment}

To evaluate the capability of Chironomidae larvae to use conditioned leaves as food we collected specimens from natural leaf packs in local streams. The streams were (1) Portugal (rio Dueça, running from a forested area into the village of Miranda do Corvo, $40^{\circ} 10^{\prime} \mathrm{N}, 8^{\circ} 23^{\prime} \mathrm{W}$ ) and (2) Minas Gerais, Brazil (Indaiá stream in the Serra do Cipó National Park $19^{\circ} 16^{\prime} \mathrm{N}, 43^{\circ} 31^{\prime} \mathrm{W}$, Pampulha reservoir in Belo Horizonte $19^{\circ} 50^{\prime} \mathrm{N}, 43^{\circ} 60^{\prime} \mathrm{W}$, and Ibirité stream a tributary of the Paraopeba $20^{\circ} 00^{\prime} \mathrm{N}, 44^{\circ} 06^{\prime} \mathrm{W}$ ). Only the Indaiá can be considered pristine; the others are affected by organic pollution. We also used (3) laboratory cultures of Chironomus riparius (IAV stock, Universidade de Coimbra), Chironomus sp. and C. xanthus (Universidade Federal de Minas Gerais).

The field specimens used in feeding trials were collected in March-April 2003 in Portugal, and in May-July 2003 in Brazil and acclimated to laboratory conditions for 1-3 days prior to the experiments. Specimens of chironomids were individually reared in Petri dishes $1.3 \mathrm{~cm}$ high containing $20 \mathrm{ml}$ of filtered stream water (GF/C, Whatman), under constant temperature similar to the local streams (i.e., $15^{\circ} \mathrm{C}$ in Portugal and $22^{\circ} \mathrm{C}$ in Brazil) and photoperiods of $12: 12 \mathrm{~h}$ and 14:10h lightdark in Portugal and Brazil, respectively. No aeration was required during the feeding trials; spot checks showed that dis- 
solved oxygen was always near saturation throughout the experiments. The number of replicates was initially 20 per species, but replicates where pupation occurred were eliminated. Portuguese chironomids were deposited at Colección del Departamento de Biología Animal, Facultad de Biología, Universidad de Santiago de Compostela (Spain), and Brazilian chironomids were deposited at Reference Collection of Benthic Macroinvertebrates, Instituto de Ciências Biológicas, Universidade Federal de Minas Gerais (Belo Horizonte, Brazil).

\section{Food}

Food was provided in the form of conditioned leaves. The European leaf species were Alnus glutinosa (L.) Gaertn., and Nerium oleander L., this one occurring in the dry Mediterranean areas of South Iberian Peninsula and North Africa. The Brazilian species were Miconia chartacea Triana (Melastomataceae), Myrcia guyanensis (Aubl.) DC. (Myrtaceae), Protium brasiliense (Spreng.) Engl., P. heptaphyllum (Aubl.) March (Bursereaceae), Solanum leucodendron Sendt. (Solanaceae), Ocotea sp. (Lauraceae), all occurring in the riparian zones of highland streams in Minas Gerais State, southeastern Brazil.

Senescent leaves were collected with nets (Serra do Cipó, Brazil) or from the ground just after abscission (Portugal), airdried and stored dry until needed. Before use in the experiments, leaves were microbial conditioned in local streams for 2 weeks (approximately $5 \mathrm{~g}$ of leaves in $0.5 \mathrm{~mm}$ mesh bags) or in a laboratory aquarium using a mixture of stream collected leaves as an inoculum and under strong aeration.

\section{Consumption}

Food was provided in the form of leaf discs. Discs were cut in pairs from contiguous areas of a same leaf. One of the discs was exposed to the chironomid, whereas the other was placed in a Petri dish with no invertebrates. Larvae were allowed to feed for a minimum of 3 days and whenever possible, adults were collected for identification. Consumption was calculated as the difference in mass between unexposed and exposed discs divided by the elapsed time in days. Values were expressed as ash free dry mass: discs were dried at $50^{\circ} \mathrm{C}$ for 2 days, weighed, ashed at $500^{\circ} \mathrm{C}$ for 5 hours and weighed again.

Feeding was considered to have occurred when the mass of exposed discs was significantly lower (pair t-test, $\mathrm{p}<0.05$ ) than the corresponding control disc (Friberg \& JACOBSEN 1994, Graça et al. 2001).

\section{RESULTS}

After 45 days in the channel, leaves of Nerium oleander lost $68 \%$ of their initial mass in coarse mesh bags, with similar results in the 0.5 and 0.25 fine mesh bags (58\% and $56 \%$ respectively). Coarse mesh bags had higher number of invertebrates than fine mesh bags: 1,028 invertebrates $\mathrm{g}^{-1}$ in $10 \mathrm{~mm}$, 495 invertebrates $\mathrm{g}^{-1}$ in $0.5 \mathrm{~mm}$, and 211 invertebrates $\mathrm{g}^{-1}$ in $0.25 \mathrm{~mm}$. Chironomids were more abundant than other invertebrates in all bags (Figs 1 and 2).

Revista Brasileira de Zoologia 24 (2): 442-448, junho 2007
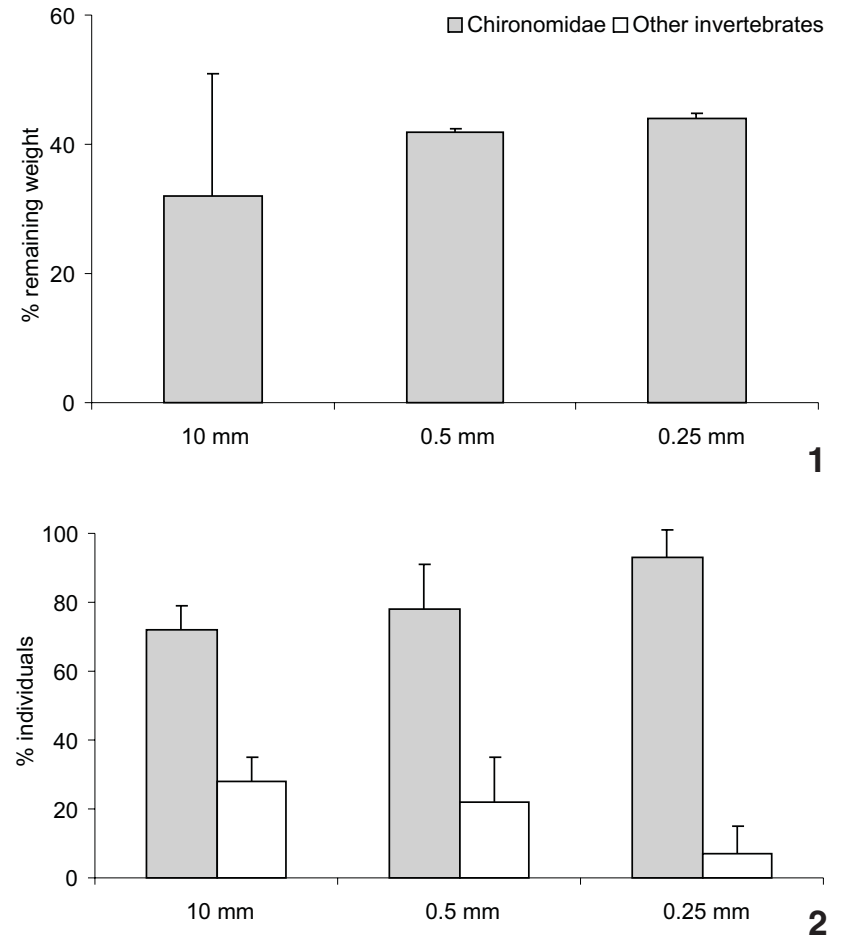

Figures 1-2. Remaining leaf weight of Nerium oleander leaves after 45 days in a stream (1) and percentage of chironomids and other invertebrates in litter bags differing in mesh size (2). Mean \pm S.E.

In Portugal the adult chironomids emerging from the feeding experiments turned to be Micropsectra apposita, Polypedilum albicorne, Eukiefferiella claripennis, Rheocricotopus (Psilocricotopus) atripes, and Ablabesmyia Johannsen, 1905. In Brazil they included Phaenopsectra Kieffer, 1921, Polypedilum Kieffer, 1912, and Chironomus Meigen, 1803. Mortality ranged from 0 to $40 \%$. Among the survivors, the percentage of larvae causing a reduction in mass of exposed leaves varied between $10 \%$ and $100 \%$ (Tab. I). Some survivors did not feed for a period of three days (up to $43 \%$ ).

Under laboratory conditions, most of the specimens consumed leaf discs (Fig. 3). Consumption rate ranged from $0.15 \pm$ 0.10 mg.animal ${ }^{-1}$ day $^{-1}$ of Micropsectra apposita in Alnus glutinosa up to $0.85 \pm 0.33 \mathrm{mg}$.animal ${ }^{-1}$ day $^{-1}$ of Polypedilum albicorne in Miconia chartacea. For the Brazilian species Phaenopsectra, Chironomus and Polypedilum no consumption was observed (Tab. I). Laboratory specimens had lower consumption rates than wild specimens (Tab. II). Maximum consumption rates reached $0.47 \pm$ 0.28 of leaf mg.animal ${ }^{-1}$ day $^{-1}$ (Chironomus on Protium heptaphilum).

\section{DISCUSSION}

In the experiments with wild specimens, survivorship under laboratory conditions ranged from 60 to 100\%. Those values are in the range of the reported for other invertebrates 


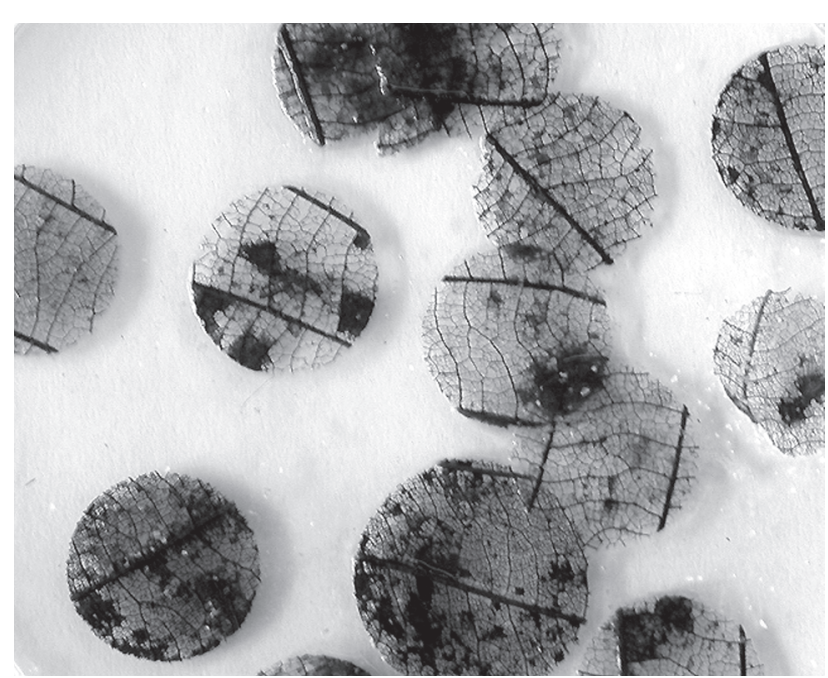

Figure 3. Leaf discs of alder (Alnus glutinosa) after being exposed to Chironomus riparius for three days under laboratory conditions.

reared under laboratory conditions (FEIo \& Graça 2000, GraÇa et al. 2001, González \& Graça 2003). Feeding rates here reported (0.06-0.85 mg animal- ${ }^{-1}$ day $\left.^{-1}\right)$ are in the upper range of values reported for other food sources: 0.04-0.27 mg animal ${ }^{-1}$ day $^{-1}$ for Pseudochironomus richardsoni Malloch, 1915 feeding on algae
(GRESENS 2001), and in the lower range of the reported for true shredders (e.g., 0.47-1.88 mg animal ${ }^{-1}$ day $^{-1}$ for Sericostomatid caddisflies; FeIo \& GraÇA 2000, WAGNER 1990). Results of consumption are probably underestimation of the real capability of larvae to feed on leaves since dead specimens and specimens which pupated had evidences of leaf tissue removal and reduction of mass in discs (not taken into account for our calculations).

Not all populations consumed leaves at the same extent. In general, laboratory populations were not able to feed on leaves. The specimens sampled in the Indaiá stream performed badly on decomposing leaves. This could be an indication that leaf litter is not an energy source for chironomids in that system or for the assayed species. Consistently, invertebrate shredders are almost absent from this stream (CALLISTO et al. 2001, Gonçalves et al. 2006b), probably due the low quality (chemical composition) of local riparian leaves in terms of hardness (MoretTi et al. 2007) and due to flush flow regime of the stream (GONÇALVEs et al. 2006a).

The field taxa Micropsectra apposita, Polypedilum albicorne, Eukiefferiella claripennis, Ablabesmyia sp. and Rheocricotopus (Psilocricotopus) atripes were able to feed on leaves. According to the literature, those species are considered gathering collectors and, to a lesser extent engulfers, piercers (just Ablabesmyia) and shredders (Grubbs \& Cummins 1994, Tavares-Cromar \& Williams 1997). In a related study GrubBs et al. (1995) also sampled Eukiefferiella claripennis (3-12\% of total chironomids), Micropsectra

Table I. Survivorship, percentage of chironomids feeding on leaves and leaf consumption ( \pm s.d.; $n=20)$ of wild specimens on conditioned leaves. (Pt) Portuguese populations, (Bz) Brazilian populations, (Ind) Indaiá stream, (Ibi) Ibirité stream.

\begin{tabular}{|c|c|c|c|c|c|}
\hline Chironomid species & Plant species & $\%$ survivorship & $\begin{array}{l}\text { \% chironomid } \\
\text { feeding }\end{array}$ & $\begin{array}{c}\text { Consumption } \\
\left(\mathrm{mg}^{\text {animal }}{ }^{-1} \cdot \text { day }^{-1}\right)\end{array}$ & Origin \\
\hline Micropsectra apposita (Walker, 1856) & Alnus glutinosa (L.) Gaertn & 75 & 100 & $0.15 \pm 0.10$ & $\mathrm{Pt}$ \\
\hline Polypedilum albicorne (Meigen, 1838) & Alnus glutinosa (L.) Gaertn & 75 & 100 & $0.17 \pm 0.04$ & $\mathrm{Pt}$ \\
\hline Polypedilum albicorne (Meigen, 1838) & Miconia chartacea Triana & 69 & 65 & $0.85 \pm 0.33$ & Pt \\
\hline Eukiefferiella claripennis Lundbeck, 1898 & Alnus glutinosa (L.) Gaertn & 77 & 65 & $0.16 \pm 0.05$ & Pt \\
\hline Eukiefferiella claripennis Lundbeck, 1898 & Nerium oleander L. & 80 & 90 & $0.23 \pm 0.06$ & Pt \\
\hline $\begin{array}{l}\text { Ablabesmyia sp. and Eukiefferiella } \\
\text { claripennis Lundbeck, } 1898^{*}\end{array}$ & Alnus glutinosa (L.) Gaertn & 100 & 57 & $0.14 \pm 0.03$ & $\mathrm{Pt}$ \\
\hline $\begin{array}{l}\text { Rheocricotopus (Psilocricotopus) atripes } \\
\text { Kieffer, } 1913\end{array}$ & Alnus glutinosa (L.) Gaertn & 73 & 70 & $0.17 \pm 0.06$ & $\mathrm{Pt}$ \\
\hline Phaenopsectra sp. Kieffer, 1921 & Miconia chartacea Triana & 100 & 0 & no consumption & Bz-Ind \\
\hline Chironominae genera varia & Miconia chartacea Triana & 100 & 35 & $0.38 \pm 0.27$ & Bz-Ind \\
\hline Chironomus spp. Meigen, 1803 & Miconia chartacea Triana & 60 & 0 & no consumption & Bz-Ind \\
\hline Polypedilum spp. Kieffer, 1912 & Miconia chartacea Triana & 70 & 0 & no consumption & Bz-Ind \\
\hline \multirow[t]{5}{*}{ Chironomus Meigen, 1803} & Miconia chartacea Triana & 100 & 80 & $0.29 \pm 0.16$ & Bz-lbi \\
\hline & $\begin{array}{l}\text { Protium heptaphilum (Aubl.) } \\
\text { March }\end{array}$ & 45 & 45 & $0.47 \pm 0.28$ & Bz-lbi \\
\hline & Ocotea sp. (Schott) Mez & 100 & 100 & $0.35 \pm 0.25$ & Bz-lbi \\
\hline & Solanum leucodendrum (TRO) & 100 & 90 & $0.33 \pm 0.28$ & Bz-lbi \\
\hline & Myrcia guyanensis Aubl. & 40 & 40 & $0.32 \pm 0.20$ & Bz-lbi \\
\hline
\end{tabular}

* Ablabesmyia sp. and Eukiefferiella claripennis were mixed in the obtained material. 
Table II. Survivorship, feeding and leaf consumption $(X \pm$ s.d.; $n=20)$ of laboratory chironomid species on conditioned leaves. (UC) University of Coimbra stock, (UFMG) Federal University of Minas Gerais stock.

\begin{tabular}{|c|c|c|c|c|c|}
\hline Chironomid species & Plant species & $\%$ Survivorship & $\begin{array}{l}\text { \% chironomid } \\
\text { feeding }\end{array}$ & $\begin{array}{c}\text { Consumption } \\
\left(\text { mg.animal }^{-1} \cdot \text { day }^{-1}\right)\end{array}$ & Origin \\
\hline Chironomus riparius Meigen, 1804 & Alnus glutinosa (L.) Gaertn & 80 & 60 & $0.06 \pm 0.07$ & UC \\
\hline \multirow[t]{4}{*}{ Chironomus xanthus Rempel, 1939} & Miconia chartacea Triana & 100 & 30 & $0.14 \pm 0.05$ & UFMG \\
\hline & Protium heptaphilum (Aubl.) March & 100 & 20 & $0.10 \pm 0.12$ & UFMG \\
\hline & Protium brasiliensis (Spreng.) Engl. & 100 & 0 & no consumption & UFMG \\
\hline & Myrcia guyanensis Aubl. & 100 & 0 & no consumption & UFMG \\
\hline \multirow[t]{3}{*}{ Chironomus Meigen, 1803} & Ocotea sp. (Schott) Mez & 50 & 10 & no consumption & UFMG \\
\hline & Protium brasiliensis (Spreng.) Engl. & 30 & 30 & $0.31 \pm 0.22$ & UFMG \\
\hline & Protium heptaphilum (Aubl.) March & 30 & 30 & $0.25 \pm 0.21$ & UFMG \\
\hline
\end{tabular}

sp. (2-19\%) and Polypedilum spp. (in lower densities) in decomposing leaves and suggested that shredding chironomids can contribute to the decomposition of fast decay rate leaves, but not to slow decay rate plant species. Eukiefferiella sp. was also reported in high densities in severely decayed wood in a stream by Collier \& Halliday (2000). Gonçalves et al. (2000, 2003, 2004) reported that Chironomids reached over $50 \%$ of total invertebrate abundance among 29 taxa colonizing detritus of aquatic macrophytes. Chironomus, Goeldichironomus, Parachironomus Lenz, 1921, Polypedilum and Rheotanytarsus Thinemann \& Bause in Bause, 1913 were the most abundant genera, reaching over $50 \%(40-70 \%)$ of detritus associated macrofauna.

We used late $\left(3^{\text {rd }}-4^{\text {th }}\right)$ instar larvae in our experiments, but in an earlier experiment with $2^{\text {nd }}$ instar of Chironomus riparius none of the individuals were able to survive up to pupation (data not shown). According to Pinder \& ReIss (1983) $1^{\text {st }}$ instar larvae of several chironomids fed mainly by diatoms, but probably because of particle size rather than diatoms per se; later instars of Eukiefferiella ilkleyensis Edwards, 1929 seem to switch to macrophytes (Ranunculus calcareous Butcher) in the $3^{\text {rd }}$ and $4^{\text {th }}$ instars. Shifts in food items in chironomids during development have also been reported by other authors (Tavares-Cromar \& Williams 1997). Therefore it is plausible that many chironomids in streams may be able to feed on decomposing leaves in instars, especially fast decomposing and well conditioned leaves. They therefore may have a contribution to decomposition of coarse particulate organic matter in streams, particularly in the summer (Grubbs \& Cummins 1994, Menendez et al. 2003) and when their densities are high.

It was frequently observed that many chironomid larvae eat the leaf tissue from the inside, between the abaxial and adaxial epidermis (CALlisto et al. 1996). Besides surface feeding, we also observed a "mining" behavior in some leaves, the construction of cases with faecal pellets, and pupation within some leaves. A set of laboratory experiments with Psectrocladius limbatellus Holmgren, 1869 processing organic matter estimated that $59 \%$ was incorporated into tubes, $39 \%$ was present in faecal pellets (HirabaYashi \& WotTon 1999).
In summary, our results show that some chironomids are able to use well conditioned leaves as food source; their role on leaf decomposition depends on their density, quality of leaves and the presence of other consumers with high efficiency using coarse particulate organic matter as food source.

\section{ACKNOWLEDGEMENTS}

This study received financial support from CNPq (Proc. 472.328/01-8), FAPEMIG (Proc. 182.303) and CAPES-GRICES Brazil-Portugal (096/03). Thanks are also due to the IBAMA and US Fish \& Wildlife Service for logistic support. Fernando Cobo from the Universidad de Santiago de Compostela (Spain) kindly identified the specimens collected in Portugal. Rui Ribeiro provided the specimens of Chironomus riparius and Arnola Rietzler offered C. xanthus and Chironomus from laboratory cultures. Valuable help during field and laboratory experiments was provided by Mary Damico, Raphael Ligeiro, Augusto Oliveira, Juliana França, Débora Lobato and Filipe Morgan.

\section{REFERENCES}

Aвelho, M. 2001. From litterfall to breakdown in streams: a review. The Scientific World 1: 656-680.

BERG, M.B. 1995. Larval food and feeding behaviour, p. 136168. In: P.D. Armitage, P.S. Cranston \& L.C.V. Pinder (Eds). The Chironomidae: biology and ecology of non-biting midges. New York, Chapman and Hall, 590p.

Callisto, M.; P. Moreno \& F.A.R. Barbosa. 2001. Habitat diversity and benthic functional trophic groups at Serra do Cipó, Southeast Brazil. Brazilian Journal of Biology 61: 259-266.

Callisto, M.; A. Serpa-Filho; S.J. Oliveira \& F.A. Esteves. 1996. Chironomids on leaves of Typha domingensis in a lagoon of Rio de Janeiro State (Brazil). Studies on the Neotropical Fauna and Environment 31: 51-53.

Canhoto, C. \& M.A.S. GraçA. 1999. Leaf barriers to fungal colonization and sheredders (Tipula lateralis) consumption of decomposing Eucalyptus globulus. Microbial Ecology 37: 163172 .

Revista Brasileira de Zoologia 24 (2): 442-448, junho 2007 
Casas, J.J.; M.C. Zamora; F. Archila \& T.J. Alba. 2000. The effect of a headwater dam on the use of leaf bags by invertebrate communities. Regulated Rivers Research and Management 16: $577-591$.

Coffman, W.P. \& L.C. Ferrington JR. 1996. Chironomidae, p. 635 753. In: R.W. Merritt \& K.W. Cummins (Eds). Introduction to the aquatic insects of North America. New York, Kendall Hunt, 862p.

Collier, K.J. \& J.N. Halliday. 2000. Macroinvertebrate-wood associations during decay of plantation pine in New Zealand pumice-bed streams: stable habitat or trophic subsidy? Journal of the North American Benthological Society 19: 94-111.

DANGLES, O. 2002. Functional plasticity of benthic macroinvertebrates: implications for trophic dynamics in acid streams. Canadian Journal of Fisheries and Aquatic Sciences 59: 1-11.

FeIo, M.J. \& M.A.S. GraçA. 2000. Food consumption by the larvae of Sericostoma vittatum (Trichoptera), an endemic species from the Iberian Peninsula. Hydrobiologia 439: 7-11.

Friberg, N. \& D. Jacobsen. 1994. Feeding plasticity of two detritivore-shredders. Freshwater Biology 32: 133-142.

Galdean, N.; M. Callisto \& F.A.R. Barbosa. 2000. Lotic ecosystems of Serra do Cipó, southeast Brazil: water quality and a tentative classification based on the benthic macroinvertebrate community. Journal of Aquatic Ecosystem Health and Management 3: 545-552.

Gessner, M.O. \& E. Chauvet. 1994. Importance of stream microfungi in controlling breakdown rates of leaf litter. Ecology 75: 1807-1817.

Gessner, M.O.; E. Chauvet \& M. Dobson. 1999. A perspective on leaf litter breakdown in streams. Oikos 85: 377-384.

Gonçalves Jr, J.F.; F.A. Esteves \& M. Callisto. 2000. Succession and diversity of Chironomidae in detritus of Typha domingensis in a coastal lagoon (Parque Nacional da Restinga de Jurubatiba, State of Rio de Janeiro, Brazil). Internationale Vereinigung für Theoretische und Angewandte Limnologie 27: 2374-2377.

Gonçalves Jr, J.F.; F.A. Esteves \& M. Callisto. 2003. Chironomids colonization in Nymphaea ampla L. detritus during a degradative ecological successional experiment in a Brazilian coastal lagoon. Acta Limnologica Brasiliensia 15: 21-27.

Gonçalves, J. F. Jr.; J. S. França; A. O. Medeiros; C. A. Rosa \& M. Callisto. 2006 a. Leaf breakdown in a tropical stream. International Review of Hydrobiology 91: 164-177.

Gonçalves JR, J.F.; M.A.S. GraçA \& M. Callisto. 2006b. Leaf litter breakdown in 3 streams in a Temperate, Mediterranean and Tropical Cerrado climates. Journal of the North American Benthological Society 25: 344-355.

Gonçalves Jr, J.F.; A.S. Medeiros \& F.A. Esteves. 2004. Influence of the chemical composition of Typha domingensis and Nymphaea ampla detritus on invertebrate colonization in a Brazilian coastal lagoon. Hydrobiologia 527: 125-137.

González, J.M. \& M.A.S. GraçA. 2003. Conversion of leaf litter to secondary production by a shredding caddis-fly. Freshwater Biology 48: 1578-1592.

GraçA, M.A.S. 2001. The role of invertebrates on leaf litter decomposition in streams - a review. International Review of Hydrobiology, Weinheim, 86: 383-393.

Graça, M.A.S.; R.C. Ferreira \& C.N. Coimbra. 2001. Litter processing along a stream gradient: the role of invertebrates and decomposers. Journal of the North American Benthological Society 20: 408-420.

Graça, M.A.S.; P. Pinto; R. Cortes; N. Coimbra; S. Oliveira; M. Morais; M.J. CarvalHo \& J. Malo. 2004. Factors affecting macroinvertebrate richness and diversity in Portuguese streams: a two-scale analysis. International Review of Hydrobiology 89: 151-164.

Gresens, S.E. 2001. Thermal sensitivity of ingestion and digestion in larvae of a eurythermal chironomid. Journal of the North American Benthological Society 20: 68-83.

GrubBs, S.A. \& K.W. Cummins. 1994. Processing and macroinvertebrate colonization of black-cherry (Prunus serotina) leaves in 2 streams differing in summer biota, thermal regime and riparian vegetation. American Midland Naturalist 132: 284-293.

Grubbs, S.A.; R.E. JacobSen \& K.W. Cummins. 1995. Colonization by Chironomidae (Insecta, Diptera) on three distinct leaf substrates in an Appalachian mountain stream. Annals de Limnologie 31: 105-118.

Hirabayashi, K. \& R.S. Wotton. 1999. Organic matter processing by chironomid larvae (Diptera: Chironomidae). Hydrobiologia 382: 151-159.

ILLIES, J. 1978. Limnofauna Europaea. Stuttgart, Spektrum Verlag, 1050p.

Menendez, M.; O. Hernandez \& F.A. Comin. 2003. Seasonal comparisons of leaf processing rates in two Mediterranean rivers with different nutrient availability. Hydrobiologia 495: 159-169.

Meyer, E.I. \& R. Poepperl. 2003. Secondary production of invertebrates in a Central European mountain stream (Steina, Black Forest, Germany). Archiv fur Hydrobiologie 158: 25-42.

Minuc, T.B. \& J.R. Minuc. 1995. Trophic ecology of five shredders in a Rocky Mountain Stream. Journal of Freshwater Ecology 10: 209-216.

Moretti, M.S.; J.F. Gonçalves Jr \& M. Callisto. 2007. Leaf breakdown in two tropical streams: Differences between single and mixed species packs. Limnologica 37: 118-129

Pinder, L.C.V. \& F. Reiss. 1983. The larvae of Chironominae (Diptera: Chironomidae) of the Holartic region - Keys and diagnoses. In: T. Wiederholm (Ed.). Chironomidae of the Holartic region - keys and diagnoses. Part 1 - Larvae. Entomological Scandinavia Supplement 19: 293-435.

Pope, R.J.; A.M. Gordon \& N.K. KaushiK. 1999. Leaf litter colonization by invertebrates in the littoral zone of a small oligotrophic lake. Hydrobiologia 392: 99-112.

Pozo, J.; E. GonzÁlez; J. Díez \& A. Elosegr. 1997. Leaf-litter budgets 
in two contrasting forested streams. Limnetica 13:77-84

Ramirez, A.; P. Paaby; C. M. Pringle \& G. Aguero. 1998. Effect of habitat type on benthic macroinvertebrates in two lowland tropical streams, Costa Rica. Revista de Biologia Tropical 46: 201-213.

REICE, S.R. 1980. The role of substratum in benthic macroinvertebrate microdistridution and litter decomposition in a woodland stream. Ecology 61: 580-590.

Rincon, J. \& C. Cressa. 2000. Temporal variability of macroin- vertebrate assemblages in a neotropical intermittent stream in Northwestern Venezuela. Archiv fur Hydrobiologie 148: 421-432.

Tavares-Cromar, A.F. \& D.D. Williams. 1997. Dietary overlap and coexistence of chironomid larvae in a detritus-based stream. Hydrobiologia 354: 67-81.

WAGNER, R. 1990. A laboratory study on the cycle of Sericostoma personatum (Kirby \& Spence) and light dark-dependent. Hydrobiologia 208: 201-212.

Received in 13.X.2006; accepted in 30.V.2007. 